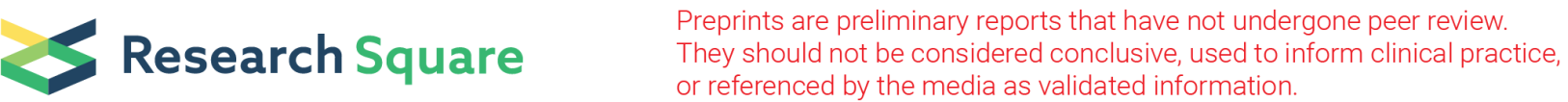

\section{What Do We Know About the Health Status of Asylum Seekers in the United States? Identifying Research Gaps Following a Bibliometric Scoping Review of Existing Literature}

\section{Jessica Beer}

Georgetown University Medical Center

C. Scott Dorris

Georgetown University Medical Center

\section{Dahlia Fateen}

Georgetown University Medical Center

Ranit Mishori ( $\square$ mishorir@georgetown.edu )

Georgetown University Medical Center

\section{Research Article}

Keywords: asylum seekers, refugees, resettlement, migration, displacement, physical health, mental health, health outcomes, health condition

Posted Date: September 8th, 2021

DOI: https://doi.org/10.21203/rs.3.rs-833067/v1

License: (c) (i) This work is licensed under a Creative Commons Attribution 4.0 International License. Read Full License

Version of Record: A version of this preprint was published at Journal of Ambulatory Care Management on January 24th, 2022. See the published version at https://doi.org/10.1097/jac.0000000000000452. 


\section{Abstract}

Background: Asylum Seekers are a high-risk group from a health perspective. The US is the largest recipient of asylum applications in the world. Multiple articles exist on asylum seekers' health, but, anecdotally, the majority originate from Europe and elsewhere. We sought to assess the current health and medical literature on asylum seekers in the US, where asylum seekers are a distinct population from refugees. This limited representation in the scientific literature can impact the care they receive. We analyzed the existing literature on asylum seekers in the US via a Scoping Review of the literature from 1946 to 2020 that discussed the health of asylum seekers in the US. Refugees were excluded given their legal status which distinguishes the protections they receive.

Results: A total of 114 articles were identified; 48 (42.1\%) of which were empirical studies; (66 (57.9\%) were editorials or commentaries. Analysis of empirical studies revealed enhanced focus on mental health $(60.42 \%)$, on African asylees (45.83\%). The majority of the editorials and commentaries focused on detention and the medico-legal process (31.82\% and $30.3 \%$ respectively).

Conclusion: Empirical data on the health of asylum seekers in the US context is very limited. Research gaps include domains that span the medical, social, and legal fields. Research expansion requires increased dedication from the research community, funding, and the ethical engagement of these vulnerable populations. This is especially important given the unprecedented migration and displacement of populations in the 21 st century.

\section{Background}

The 21st century has, so far, been a time of unprecedented migration and displacement of populations. The majority of this movement is due to economic migration, but a notable number of people have been forcibly displaced due to conflict, persecution, or disaster events. According to the UNHCR, 79.5 million people have been displaced in 2019 alone - the highest number since 2000 [1]. The people in this group generally fall into one of four categories: internally displaced persons, stateless persons, refugees, and asylum seekers.

The US has been home to 3 million refugees since 1975 and has accepted an average of 24,000 asylum seekers annually since 1990 (with some fluctuation due to policy restrictions during the Trump administration) [2,3]. Both refugees and asylum seekers are persons unable or unwilling to return to their nation of origin due to persecution or fear of persecution. However, while refugees to the United States have legal protection and have been accepted into this country prior to their arrival, asylum seekers are a distinct group in that they have arrived in a country of refuge (such as the United States or at its border) but do not yet have legal recognition.

According to the UN World Migration Report, there are over 700,000 asylum seekers in the U.S. with over 250,000 claims made in 2018 alone [4]. This makes the U.S. the largest recipient of asylum applications in the world. Unlike refugees who come to the US already receiving the support of resettlement agencies, 
asylum seekers do not have assistance, health insurance, or access to public or private resources. As a result, this group is particularly vulnerable in terms of health access, risks, and outcomes.

Despite this clear high-risk status, relatively little has been published about the particular health problems of asylum seekers in the United States. A few of the existing studies have begun to shed light on this issue, one study noting that more than half of the participants of US asylees had chronic health issues and another study noting $100 \%$ prevalence of mental health issues in one population (Bosnian torture survivors) and more than $50 \%$ prevalence in another (Colombian torture survivors) $[5,6]$. Despite these findings, another study found that $57 \%$ of the studied asylum seekers did not have any contact with the healthcare system, despite almost all having physical and psychological conditions [7]. A study looking specifically at asylum seekers who were pregnant found several previously undetected health problems placing them at risk of potentially poor pregnancy outcomes [8].

In contrast, the US medical literature is quite robust when it comes to the health status and outcomes of refugees. For example, one study assessed the health of refugee children arriving at major ports of entry in the United States and was able to create health profiles based on country of origin [9]. Data established in this manner allows for the stratification of health needs and recommended medical care for these populations. The impact of such research also extends beyond their medical health and assists with readjustment and integration into their new environments.

There are many health issues that arise as a result of the movement of people across borders. The latest coronavirus pandemic is just one example, but the World Migration Report points out the limited nature of evidence-based medicine and research into the health of migrating populations and their host nations. Most of the literature is about populations arriving in developed, rather than developing countries and the most commonly studied migrant category is "refugees and asylum seekers" (as one group) [10].

The literature on asylum seekers in Europe and elsewhere appears to be quite robust, (though differing definitions of "asylum seekers" make this somewhat difficult to study). Gerritsen, et. al performed a population-based study of refugees and asylum seekers in the Netherlands and found that the health problems of asylum seekers were more numerous than those of refugees [11]. A WHO report about the health problems of refugees and asylum seekers in Europe found that the asylum process itself can significantly impact health: prolonged proceedings, extended periods in detention, and threat of deportation all have negative effects on an already vulnerable population

In contrast to the body of knowledge about refugees in both the U.S. and around the world, as well as asylum seekers in other countries, there appear to be few articles related to the specific health concerns of asylum seekers in the U.S. We sought to perform a bibliometric review of the literature about the health of asylum seekers in the US as a means to identifying gaps in our understanding of the health status, disease prevalence, and other issues affecting the health of asylum seekers, and make recommendations for future studies. 


\section{Methods}

We used a Scoping Review Methodology [12]. The search strategy included a search of Medline, Embase, Global Health, and CINAHL databases using search terms as follows: TI ("seek asylum" OR "seeking asylum" OR "asylum seeking" OR "asylum seeker" OR "asylum seekers" OR asylee OR asylees) OR AB ("seek asylum" OR "seeking asylum" OR "asylum seeking" OR "asylum seeker" OR "asylum seekers" OR asylee OR asylees).

The inclusion criteria consisted of articles within United States or at its borders; Type of Population: Asylum Seekers, separate from Refugees and/or migrants; Types of Research studies: All published qualitative and quantitative research studies dealing with all aspects of health as defined by the World Health Organization: physical, mental, and social well-being; Other publications: All Commentaries, letters to the Editor, Background articles dealing with Asylum Seekers and health; Date of publication: 1946 to February 1st, 2020 for articles.

Articles from/about other countries, involving migrant or refugee populations without specific reference to asylum seeker status, books, interviews, abstracts, conference proceedings, poster presentations were excluded.

Articles and abstracts were uploaded to the Rayyan QCRI database management application and the initial screening process separated articles based on location of asylum seekers: within the U.S. and "Non-U.S." Following this initial screening, full texts of articles were uploaded.

As this is a bibliometric analysis not involving human subjects or primary data about human subjects, the project did not require IRB approval.

\section{Results}

In total, 2942 documents were retrieved after duplicates were removed. Ninety-one percent of the articles $(2,689)$ were removed in the initial screening due to the study or article originating in a host country outside the U.S. There were 253 full-text articles assessed of which 139 (55\%) were determined not to fit the inclusion criteria (the majority of these were excluded because they did not separate refugee and asylum seeker populations). Of the 114 articles that remained, 48 (42.1\%) were empirical studies, while the rest (66 or $57.9 \%$ ) were editorials or commentary articles. Figure 1 presents the PRISMA flow diagram of the articles included in this analysis.

Of the 48 empirical studies analyzed, the majority ( 29 of 48 or $60.42 \%$ ) focused on mental health while $41.67 \%$ focused on physical health. Of the latter, only 2 of 48 studies (4.2\%) investigated chronic illness such as coronary artery disease, diabetes and obesity, while only 3 of $48(6.25 \%)$ looked at communicable diseases such as TB, HIV or Hepatitis A, B or C. Solely $8 \%$ addressed coping mechanisms and $22.9 \%$ addressed barriers to treatment. Articles were more frequently related to African asylum seekers (45.83\%), followed by those about individuals from the Americas and Asia. Only one study ( $2 \%$ ) 
focused on a pediatric population while $16.67 \%$ and $22.92 \%$ studied LGBT asylum seekers and survivors of SGBV.

For the commentaries analyzed, unlike the empirical studies, detention was the topic most discussed (20 of $66,30.3 \%)$. Only 5 articles referred to physical sequelae, specifically torture $(7.58 \%)$. There were no articles talking about mental health specifically, and it was only alluded to with 2 articles on reliance \& coping mechanisms (3.03\%) and 2 on discrimination and prejudice faced in the US (3.03\%). Similar to the empirical studies, $21.21 \%$ addressed barriers to treatment. Notably, there were no studies that discussed LGBT asylum seekers and only 1 that discussed survivors of SGBV (1.52\%). However, there was a larger focus on the pediatric population (18.18\%) and a smaller focus on torture survivors (12.12\%).

Table 1 summarizes the focus areas that were studied in the 114 articles analyzed, both empirical studies and commentaries. 
Table 1

Summary of the focus areas that were studied in the 114 articles analyzed, both empirical studies and commentaries

\begin{tabular}{|c|c|c|}
\hline & Empirical Studies & Editorials/Commentaries \\
\hline & $N=48$ & $N=66$ \\
\hline & Outcome. Number (percent) & Outcome. Number (percent) \\
\hline Health & 1. Depression, Anxiety, PTSD. 29 (60.42\%) & 1. Torture. 5 (7.58\%) \\
\hline & 2. Physical sequelae of torture. $20(41.67 \%)$ & \\
\hline & 3. Other. $12(25 \%)$ & \\
\hline & $\begin{array}{l}\text { (i.e. Non/Communicable diseases }-3 \text {; } \\
\text { Women's health }-2 \text {; Obesity }-2 \text {; Chronic pain } \\
-1 \text { ) }\end{array}$ & \\
\hline Region of & 1. Africa. $22(45.83 \%)$ & \\
\hline & 2. North America. 19 (39.58\%) & \\
\hline & 3. Asia. 14 (29.17\%) & \\
\hline & 4. Europe. $11(22.92 \%)$ & \\
\hline & 5. Global/multiple. 10 (20.83\%) & \\
\hline & 6. Unknown/Did not say. 3 (6.25\%) & \\
\hline Population & 1. Torture Survivors. 19 (39.58\%) & 1. Torture survivors. $8(12.12 \%)$ \\
\hline & 2. Survivors of SGBV. 11 (22.92\%) & 2. SGBV. $1(1.52 \%)$ \\
\hline & 3. LGBTQ. 8 (16.67\%) & 3. LGBTQ. $0(0 \%)$ \\
\hline & 4. Children. 1 (2.08\%) & 4. Children. 12 (18.18\%) \\
\hline Specific topics & 1. Medico-legal processes. $13(27.08 \%)$ & 1. Medico-Legal Processes / \\
\hline (top 4) & 2. Torture. $12(25 \%)$ & $(31.82 \%)$ \\
\hline & $\begin{array}{l}\text { 3. Health systems infrastructure and outcomes. } \\
12(25 \%)\end{array}$ & 2. Detention. 20 (30.3\%) \\
\hline & 4. Treatment / Barriers to treatment. 11 & $\begin{array}{l}\text { 3. Health systems infrastructure } \\
\text { and outcomes. } 15(22.73 \%)\end{array}$ \\
\hline & & $\begin{array}{l}\text { 4. Treatment / Barriers to } \\
\text { treatment. } 14(21.21 \%)\end{array}$ \\
\hline Type of Study & 1. Qualitative. $13(27.08 \%)$ & \\
\hline & 2. Quantitative. 26 (54.17\%) & \\
\hline & 3. Case Study. 6 (12.5\%) & \\
\hline & 4. Mixed Methods. 2 (4.17\%) & \\
\hline
\end{tabular}


Percentages do not add up to $100 \%$ because there was overlap in many of the studies. For example, a number of studies focused on both physical and mental aspects of health and very few studies looked at asylum seekers from just one country or region of the world. As a result, most of the articles fit into multiple categories and so were "counted" more than one time.

Table 2 reviews that areas highlighted in the 48 empirical studies we analyzed. 
Table 2

Summary of the focus areas that were studied in the 48 empirical studies analyzed.

Summary table based on $\mathbf{4 8}$ articles (U.S. studies)

Characteristic

Number

(\%)

Type of study and (qual/quant)

Quantitative

Qualitative

13

(27.08\%)

Case Study

6

(12.5\%)

Mixed method

2

$(4.17 \%)$

Type of health outcome studied

Mental

Social well-being

21

(43.75\%)

Physical

20

None

1

$(2.08 \%)$

Specific Health Condition

PTSD/A/D

Physical sequelae of torture

13

(27.08\%)

Others

12 (25\%)

None

11

(22.9\%)

Country/Region of origin

Africa

America 
Summary table based on 48 articles (U.S. studies)

Asia

Europe

11

(22.92\%)

Globe

10

(20.83\%)

Unknown

3

(6.25\%)

Population focus subcategories

Torture survivors

SGBV

11

(22.92\%)

LGBT

8

(16.67\%)

Children

1

$(2.08 \%)$

Study focus subcategories

Medico-Legal Processes / Asylum evaluations

Health systems infrastructure and outcomes (housing, employment, access to insurance and other programs)

Torture

Treatment / Barriers to treatment

Training \& Education

5

$(10.42 \%)$

Resilience / coping mechanisms

4

$(8.33 \%)$

U.S. Discrimination / Prejudice

4

(8.33\%)

Detention

3

(6.25\%)

US/Mexico Border

2

(4.17\%)

Age Assessment

$0(0 \%)$ 
Table 3 summarizes the focus areas of the 66 editorials and commentaries analyzed.

Table 3

Summary of the areas that were the focus of the 66 editorials and commentaries analyzed.

\begin{tabular}{|ll|}
\hline \multicolumn{2}{|l|}{ Summary table based on 66 articles (Editorial, Commentary articles) } \\
\hline Characteristic & Number (\%) \\
\hline Subject characteristics & $12(18.18 \%)$ \\
\hline Children & $\mathbf{8 ( 1 2 . 1 2 \% )}$ \\
\hline Torture survivors & $1(1.52 \%)$ \\
\hline SGBV & $0(0 \%)$ \\
\hline LGBT & \\
\hline Topic subcategories & $21(31.82 \%)$ \\
\hline Medico-Legal Processes / Asylum evaluations & $20(30.3 \%)$ \\
\hline Detention & $15(22.73 \%)$ \\
\hline Health systems infrastructure and outcomes & \\
\hline (housing, employment, access t insurance and other programs) & $14(21.21 \%)$ \\
\hline Treatment / Barriers to treatment & $11(16.67 \%)$ \\
\hline US/Mexico Border & $7(10.61 \%)$ \\
\hline Training \& Education & $5(7.58 \%)$ \\
\hline Torture & $2(3.03 \%)$ \\
\hline Discrimination / Prejudice (in U.S.) & $2(3.03 \%)$ \\
\hline Resilience / coping mechanisms & $2(3.03 \%)$ \\
\hline Age Assessment & \\
\hline
\end{tabular}

When reviewing the temporal association of the number of articles published by year of publication it appears that interest in the topic of asylum seeker health has grown in recent years, but editorial/commentary articles far outpace actual research studies in the U.S. Figure 2 provides a scatterplot of the type of articles included in this study and the years the articles were published.

\section{Discussion}

Our bibliometric review of the literature on the health of asylum seekers in the US reveals that the scope of content is quite limited in terms of areas covered, with the majority of empirical studies focusing on 
the mental health of asylum seekers. Mental health, of course, is important and is tightly linked to the experience of forced migration, however, it limits our ability to understand common medical conditions and prepare to address them systematically.

Despite being the number one country for asylum applications, the US has poor representation in the scientific literature on the health of asylum seekers. This may be related to a few factors, including: a health system that does not prioritize research about this population and very limited funding mechanisms, asylum medicine being a very 'niche' area of investigation and involving only a small group of dedicated researchers. There may also be decreased awareness about the difference in status between refugees and asylum seekers, with the two being distinct groups that merit their own assessments. Notably, asylum seekers hold more historic presence and volume in Europe following World War 2, which explains the explicit mention in the 1951 Geneva Convention. In the US, domestic legal provisions to protect asylum seekers and enshrine the process is more recent and dates back to the Refugee Act of 1980. With regards to the asylee population specifically, it may also be possible that they are hard to reach because some are 'flying under the radar' while awaiting their legal proceedings. The legal stigma from within and outside their community may often serve as a barrier to their prioritization.

In terms of volume, and perhaps due to difficulties producing empirical research, there appear to be more scholarly products in the form of commentary than empirical research. In that category, commentaries about children seeking asylum and the health effects during detention (on both children and adults) are much more common, perhaps reflecting the current political situation and recent immigration policies.

Our project has a few weaknesses. This bibliometric assessment is not a comprehensive list of all studies, as we did not review or explore the grey literature, poster or conference presentations.

We also did not perform analysis of the non-U.S. studies for direct comparison with US-based content. The time limitations of this project mean that we are missing articles that have been published since we stopped reviewing the literature on February 1st, 2020. Anecdotally, multiple studies have appeared in recent months reflecting heightened interest given the politicization of asylum and the COVID-19 pandemic

Judging by temporal trends in publication, research productivity in other countries, and, anecdotally, the increasing number of asylum-related content in conferences related to forced migration, asylum medicine is a growing field just beginning to establish itself in the US.

This bibliometric evaluation might help identify research gaps, and aid US-based researchers in coming to a consensus on what we may want to study related to the health of asylum seekers, that could help push the field forward and assist with the provision of evidence-based care and research-informed services. Table 4 provides suggested areas that merit enhanced research efforts in Asylum Seekers' health. 
Table 4

Potential areas that merit enhanced research efforts.

\begin{tabular}{|c|c|c|}
\hline Domain & Questions & Examples and applications \\
\hline \multirow[t]{4}{*}{ Clinical/Medical } & \multirow[t]{4}{*}{$\begin{array}{l}\text { What is the prevalence of certain conditions } \\
\text { in asylum seekers? }\end{array}$} & $\begin{array}{l}\text { - Evidence Based Screening } \\
\text { (certain infectious diseases, } \\
\text { STIs) }\end{array}$ \\
\hline & & $\begin{array}{l}\text { - Non-communicable } \\
\text { diseases (trends, screening, } \\
\text { management, education) }\end{array}$ \\
\hline & & $\begin{array}{l}\text { - Oral Health (trends, } \\
\text { screening, management, } \\
\text { education) }\end{array}$ \\
\hline & & $\begin{array}{l}\text { - Nutrition (vitamin } \\
\text { deficiencies) (trends, } \\
\text { screening, management, } \\
\text { education) }\end{array}$ \\
\hline \multirow[t]{3}{*}{ Epidemiological } & \multirow[t]{3}{*}{$\begin{array}{l}\text { What are some population trends in asylum } \\
\text { seekers? }\end{array}$} & $\begin{array}{l}\text { - Demographics: age, gender, } \\
\text { special populations (e.g } \\
\text { disability, LGBTQ) }\end{array}$ \\
\hline & & $\begin{array}{l}\text { - Disease prevalence and } \\
\text { distribution (NCD, } \\
\text { communicable) }\end{array}$ \\
\hline & & $\begin{array}{l}\text { - Prevalence of specific } \\
\text { conditions (violence, torture, } \\
\text { SGBV). }\end{array}$ \\
\hline \multirow[t]{3}{*}{$\begin{array}{l}\text { Behavioral/Mental } \\
\text { Health }\end{array}$} & \multirow{3}{*}{$\begin{array}{l}\text { What are the factors that influence the } \\
\text { development or exacerbation of } \\
\text { behavioral/mental health conditions in this } \\
\text { population? }\end{array}$} & $\begin{array}{l}\text { - Identification of behavioral } \\
\& \text { mental health issues } \\
\text { (screening instruments) }\end{array}$ \\
\hline & & $\begin{array}{l}\text { - Assessment of risk factors } \\
\text { (type of trauma exposure, } \\
\text { setting of relocation) }\end{array}$ \\
\hline & & $\begin{array}{l}\text { - Alleviating factors } \\
\text { (resilience and protective } \\
\text { features, treatment } \\
\text { modalities, advocacy) }\end{array}$ \\
\hline \multirow{3}{*}{$\begin{array}{l}\text { Specific Conditions } \\
\text { Associated with } \\
\text { Forced Migration } \\
\text { (torture) }\end{array}$} & \multirow[t]{3}{*}{$\begin{array}{l}\text { What are the sequelae of torture and how } \\
\text { can they be addressed? }\end{array}$} & $\begin{array}{l}\text { - Long term } \\
\text { physical/psychological } \\
\text { consequences }\end{array}$ \\
\hline & & $\begin{array}{l}\text { - Specific types of torture acts } \\
\text { and their medical } \\
\text { manifestations }\end{array}$ \\
\hline & & $\begin{array}{l}\text { - Protective modifiers for long } \\
\text { term mental health burden }\end{array}$ \\
\hline
\end{tabular}




\begin{tabular}{|c|c|c|}
\hline Domain & Questions & Examples and applications \\
\hline \multirow{2}{*}{$\begin{array}{l}\text { Specific Conditions } \\
\text { Associated with } \\
\text { Forced Migration } \\
\text { (SGBV) }\end{array}$} & \multirow[t]{2}{*}{$\begin{array}{l}\text { What are the sequelae of SGBV and how } \\
\text { can they be addressed? }\end{array}$} & $\begin{array}{l}\text { - Long term } \\
\text { physical/psychological } \\
\text { consequences }\end{array}$ \\
\hline & & $\begin{array}{l}\text { - Protective modifiers for long } \\
\text { term mental and health } \\
\text { related burdens }\end{array}$ \\
\hline \multirow[t]{3}{*}{ Medico-Legal } & \multirow[t]{3}{*}{$\begin{array}{l}\text { What are the avenues and grant rates of } \\
\text { asylum seeking? }\end{array}$} & $\begin{array}{l}\text { - Evaluation of asylum } \\
\text { programs }\end{array}$ \\
\hline & & $\begin{array}{l}\text { - Mapping asylum grant rates } \\
\text { to geography, type of request, } \\
\text { special grounds }\end{array}$ \\
\hline & & $\begin{array}{l}\text { - Effect of medical evaluation } \\
\text { on asylum grant rate }\end{array}$ \\
\hline \multirow[t]{4}{*}{$\begin{array}{l}\text { Comparative } \\
\text { Outcomes }\end{array}$} & \multirow{4}{*}{$\begin{array}{l}\text { What are the factors impacting asylum } \\
\text { seekers outcomes in the US and how do } \\
\text { they compare? }\end{array}$} & $\begin{array}{l}\text { - Impact of detention on } \\
\text { health }\end{array}$ \\
\hline & & $\begin{array}{l}\text { - Comparative outcomes } \\
\text { depending on point of } \\
\text { entrance }\end{array}$ \\
\hline & & $\begin{array}{l}\text { - Comparative outcomes of } \\
\text { immigrants vs. refugees }\end{array}$ \\
\hline & & $\begin{array}{l}\text { - US outcomes vs. Europe, } \\
\text { Canada }\end{array}$ \\
\hline \multirow{5}{*}{$\begin{array}{l}\text { Social Determinants } \\
\text { of Health }\end{array}$} & \multirow{5}{*}{$\begin{array}{l}\text { What is the impact of the social landscape } \\
\text { in the US on asylum seeker health? }\end{array}$} & - Impact of housing instability \\
\hline & & - Impact of job instability \\
\hline & & $\begin{array}{l}\text { - Access to insurance; } \\
\text { healthcare }\end{array}$ \\
\hline & & - Language barriers \\
\hline & & $\begin{array}{l}\text { - Impact of immigration } \\
\text { enforcement }\end{array}$ \\
\hline \multirow[t]{3}{*}{$\begin{array}{l}\text { Health Profession } \\
\text { Education }\end{array}$} & \multirow{3}{*}{$\begin{array}{l}\text { What processes exist to train health } \\
\text { professionals about asylum seekers as a } \\
\text { special patient population? }\end{array}$} & $\begin{array}{l}\text { - Mapping of curricular } \\
\text { initiatives and outcomes }\end{array}$ \\
\hline & & $\begin{array}{l}\text { - Mapping of extracurricular } \\
\text { opportunities and outcomes }\end{array}$ \\
\hline & & $\begin{array}{l}\text { - Comparative training and } \\
\text { contribution of different } \\
\text { health professionals }\end{array}$ \\
\hline
\end{tabular}




\begin{tabular}{|lll|}
\hline Domain & Questions & Examples and applications \\
\hline Integration and & What avenues and barriers exist in \\
Acculturation & facilitating the acculturation of asylum & - Health care navigation \\
& seekers? & - Language and literacy \\
& & interventions \\
& - Participation in research \\
\hline
\end{tabular}

A key factor in any efforts to expand research about asylum seekers would be how to ethically involve this unique population in research in a manner that is linguistically and culturally appropriate, and that reflects on their priorities. Importantly, serious considerations must be given to concerns about safety, confidentiality and fears related to immigration status $[13,14]$. Participatory research with this population has shown the value of a joint approach to the identification of needs and solutions, specifically noting that the pre-conceived notions from both the general public and the asylee population can often widen existing inequalities and create additional barriers [15].

\section{Declarations}

Ethics approval and consent to participate: N/A. This is a bibliometric analysis and does not involve human subjects. IRB approval was not indicated.

Consent for publication: N/A

Availability of data and materials: The datasets used and/or analyzed during the current study are available from the corresponding author on reasonable request.

Competing interests: All the authors declare that they have no competing interests

Funding: we had no funding.

Authors' contributions: The roles each author assumed in the preparation of this manuscript are: Study concept (RM, JB); Development and implementation of methods (RM, JB, SD; Data review and analysis (all); Manuscript preparation (All). All authors have reviewed the submitted manuscript and approved the final version of the manuscript for submission.

Acknowledgements: We have none.

Authors' information (optional)

\section{References}

1. United Nations High Commissioner for Refugees (UNHCR). Global trends: Forced displacement in 2017.. https://www.unhcr.org/5b27be547.pdf. Accessed December 5, 2018. 
2. Refugees in America. USA for UNHCR, www.unrefugees.org/refugee-facts/usa/. Accessed January 19, 2021.

3. Department of Homeland Security. Refugees and Asylees. 22 Oct. 2020, www.dhs.gov/immigrationstatistics/refugees-asylees. Accessed January 19, 2021.

4. International Organization for Migration (IOM). World Migration Report 2020. United Nations; 2019. doi:10.18356/b1710e30-en

5. Dookeran NM, Battaglia T, Cochran J, Geltman PL. Chronic disease and its risk factors among refugees and asylees in Massachusetts, 2001-2005. Prev Chronic Dis. 2010 May;7(3):A51. Epub 2010 Apr 15.

6. Alexander A, Blake S, Bernstein MA. The staying power of pain. A comparison of torture survivors from Bosnia and Colombia and their rates of anxiety, depression and PTSD. Torture. 2007;17(1):110.

7. Asgary R, Saenger P, Jophlin L, Burnett DC. Domestic global health: a curriculum teaching medical students to evaluate refugee asylum seekers and torture survivors. Teach Learn Med. 2013;25(4):348-57.

8. Kahler LR, Sobota CM, Hines CK, Griswold K. Pregnant women at risk: an evaluation of the health status of refugee women in Buffalo, New York. Health Care Women Int. 1996 Jan-Feb;17(1):15-23.

9. Yun K, Matheson J, Payton C, et al. Health Profiles of Newly Arrived Refugee Children in the United States, 2006-2012. Am J Public Health. 2016;106(1):128-135.

10. Centers for Disease Control and Prevention. Refugee Health Guidance. https://www.cdc.gov/immigrantrefugeehealth/guidelines/refugee-guidelines.html. Published March 16, 2021. Accessed January 19, 2021.

11. Gerritsen AAM, Bramsen I, Devillé W, et al. Physical and mental health of Afghan, Iranian and Somali asylum seekers and refugees living in the Netherlands. Soc Psychiat Epidemiol. 2006;41(1):18-26.

12. United Nations High Commissioner for Refugees (UNHCR) Global Trends - Forced Displacement in 2018. UNHCR Global Trends 2018, 20 June 2019, www.unhcr.org/globaltrends2018/.

13. Ziersch A., Due C., Arthurson K., Loehr N. (2019) Conducting Ethical Research with People from Asylum Seeker and Refugee Backgrounds. In: Liamputtong P. (eds) Handbook of Research Methods in Health Social Sciences. Springer, Singapore.

14. Halilovich $\mathrm{H}$. Ethical approaches in research with refugees and asylum seekers using participatory action research. Values and Vulnerabilities: The Ethics of Research with Refugees and Asylum Seekers. Published online 2013:127-150.

15. Quinn N. Participatory action research with asylum seekers and refugees experiencing stigma and discrimination: the experience from Scotland. Disability \& Society. 2014;29(1):58-70.

\section{Figures}


PRISMA 2009 Flow Diagram: Figure 1

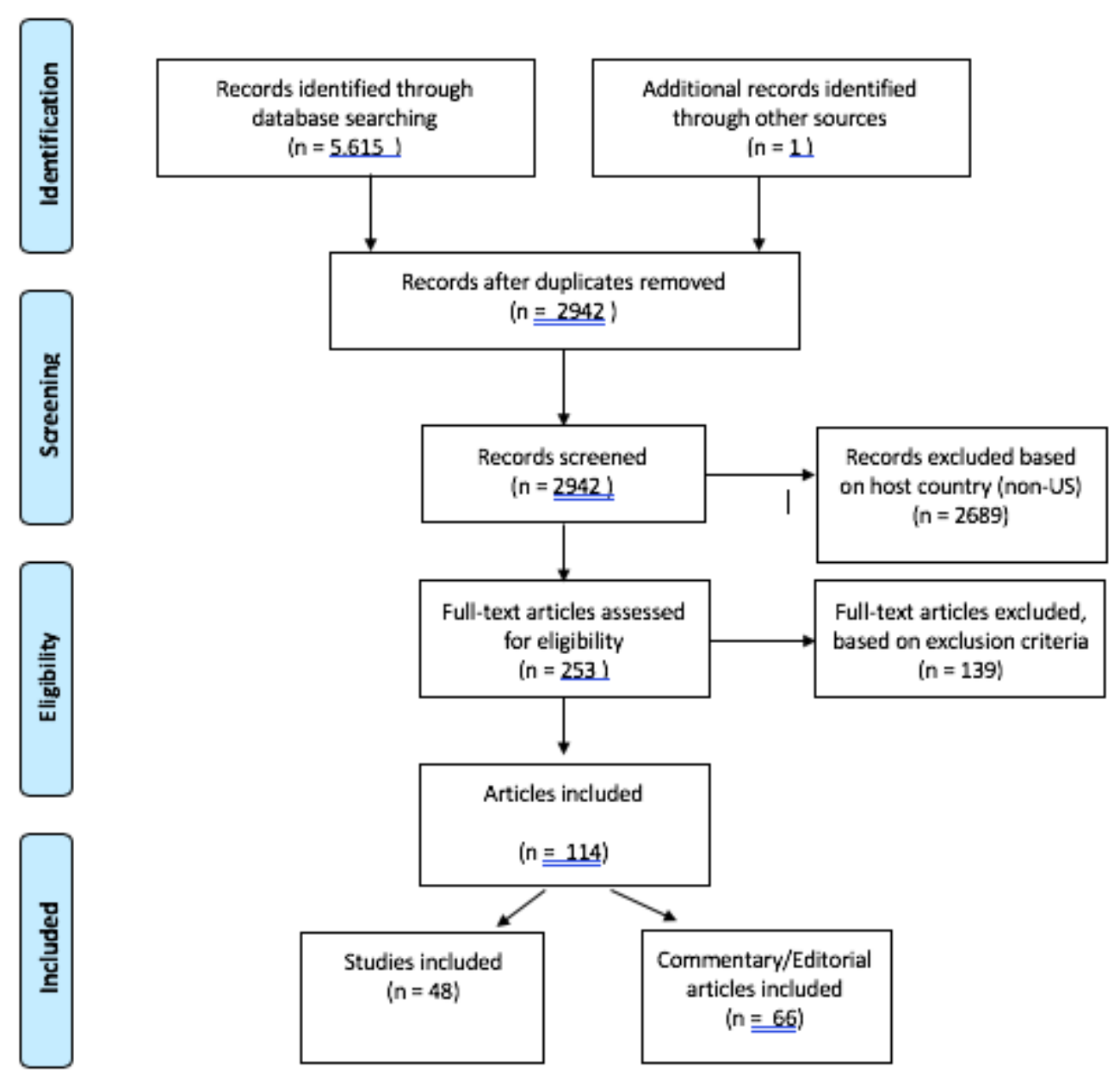

Figure 1

PRISMA flow diagram of the articles included in this analysis. 


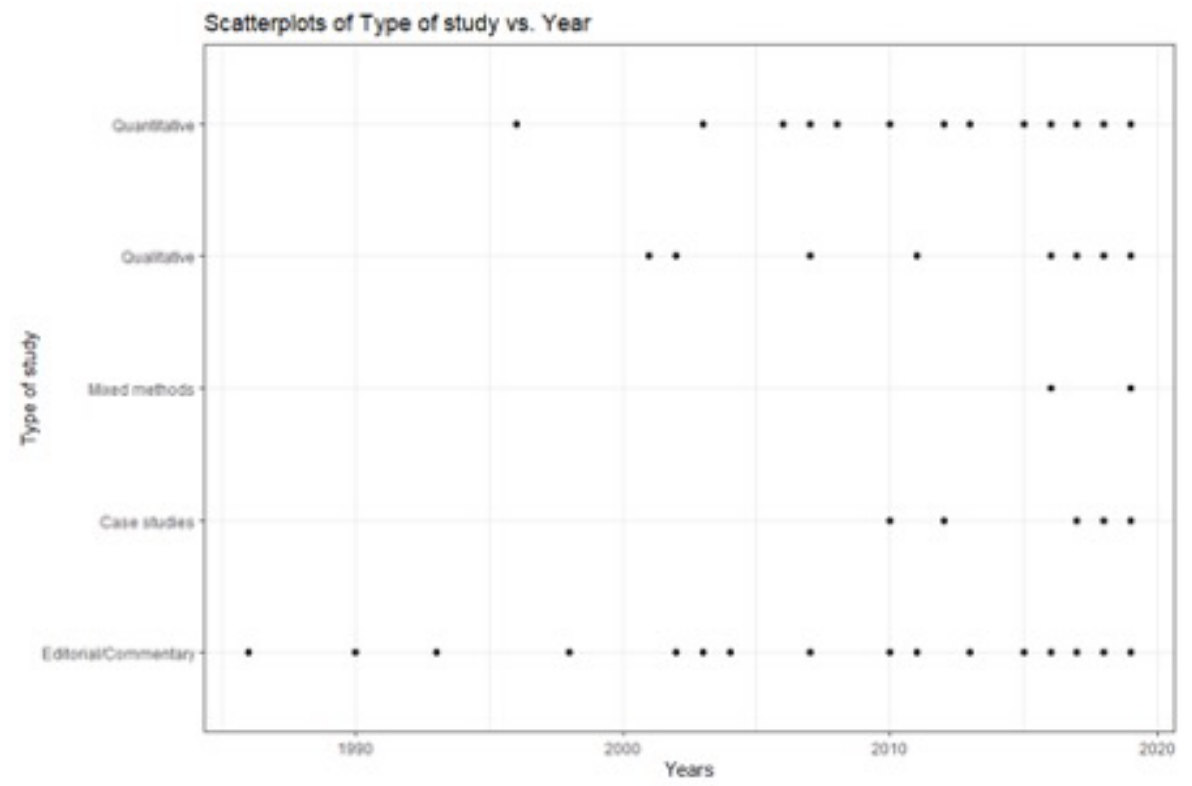

Figure 2

Scatterplot of the type of articles included in this study and the years the articles were published. 